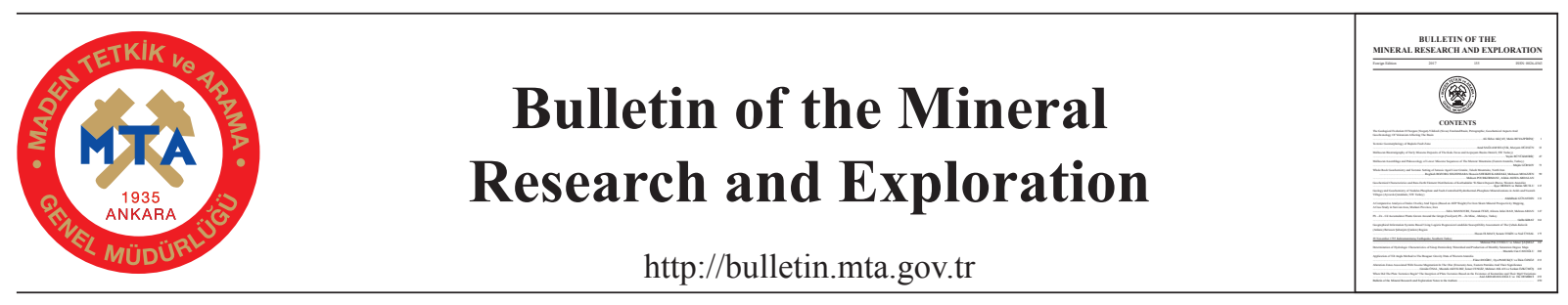

\title{
A COMPARATIVE ANALYSIS OF INDEX OVERLAY AND TOPSIS (BASED ON AHP WEIGHT) FOR IRON SKARN MINERAL PROSPECTIVITY MAPPING, A CASE STUDY IN SARVIAN AREA, MARKAZI PROVINCE, IRAN
}

\author{
Edris MANSOURİ ${ }^{\mathrm{a}}$, Faranak FEİZi ${ }^{\mathrm{b}}$, Alireza Jafari RAD ${ }^{\mathrm{c}}$ and Mehran ARİAN ${ }^{\mathrm{d}}$ \\ ${ }^{a}$ Department of Geology, Science and Research branch, Islamic Azad University, Tehran, Iran; Mailing address: Science and Research \\ branch, Hesarak, Tehran, Iran, Postal code: 1477893855; orcid no: 0000-0001-7522-885X \\ ${ }^{b}$ Mining Engineering Department, South Tehran Branch, Islamic Azad University, Tehran, Iran; Mailing address: Central Office of South \\ Tehran Branch, Islamic Azad University, North Iranshahr Street, Karimkhan Zand Street, Tehran, Iran, Postal code: 4435/11365; orcid \\ no:0000-0003-2863-4497 \\ ${ }^{c}$ Department of Geology, Science and Research branch, Islamic Azad University, Tehran, Iran; Mailing address: Science and Research \\ branch, Hesarak, Tehran, Iran, Postal code: 1477893855; orcid no:0000-0002-4371-0841 \\ ${ }^{d}$ Department of Geology, Science and Research branch, Islamic Azad University, Tehran, Iran; Mailing address: Science and Research \\ branch, Hesarak, Tehran, Iran, Postal code: 1477893855; orcid no0000-0002-4574-5116
}

Research Article

Keywords:

TOPSIS, Index Overlay,

AHP, Iron Skarn, Iran.
Received Date: 07.10 .2016 Accepted Date: 22.02.2017

\begin{abstract}
The aim of this research is to compare index overlay and TOPSIS (based on AHP weight) for predictive Skarn potential map. In this paper, for Calcic Iron Skarn mineralization, criteria and subcriteria introduced and ranked for generating mineral prospectivity map. The values of final prospecting maps for Skarn deposit by index overlay and TOPSIS methods was specified by dividing the prospectivity values into 10 classes. For better comparison, values assign to classes base on their priority in mineral exploration. The comparative analyses of index overlay and TOPSIS integration methods, has been performed by selecting four GCPs for field checking. Field observation in GCP 1, 2 and 3, confirmed Iron mineralization in the contact of intrusive bodies with sedimentary units, where the contact metamorphism was obvious but there is no observable mineralization in GCP4. Although high magnetic is distinct in mentioned GCP. Based on the field checking in Sarvian area, the TOPSIS method has more accuracy compared to index overlay approach. Therefore, the TOPSIS method recommends for Calcic Iron Skarn Mineral Prospectivity Mapping in Sarvian and adjacent area.
\end{abstract}

\section{Introduction}

Discovering new mineral deposits and diagnosing prospective zones within the region of interest, is the ultimate purpose of mineral exploration. To achieve this goal, multiple datasets, or layers should be collected, analyzed and integrated for mineral prospectivity mapping (MPM) in the region of interest (Bonham-Carter, 1994; Carranza, 2008; Abedi et al., 2013; Najafi et al., 2014). There is obscure information on evaluating geo-evidential features as indicators for exploration of a desirable and appropriate deposit type, as a result of the complexity of geological scopes.

In mineral exploration, datasets are geo-datasets. Hence, MPM generates a predictive model for tracing prospective regions as a multiple criteria decision- making (MCDM) function. In this manner producing evidential maps, combining evidential maps, and finally ranking promising target areas for further exploration have been performed. There are four types of methods to appropriate evidential weights and combine evidential maps for MPM. Evidential class weights can be assigned (1) based on the expert judgment of analyst through an approach called knowledge-driven MPM, for example, using index overlay and Boolean logic techniques (BonhamCarter, 1994; Carranza and Hale, 2001; Rogge et al., 2006), (2) by using the locations of known mineral occurrences as training points through an approach called data-driven MPM (Bonham-Carter, 1994; Porwal et al., 2003), and (3) by using a hybrid of the two aforementioned approaches to MPM (Porwal et

\footnotetext{
*Corresponding author: Faranak FEİi faranakfeizi@gmail.com http://dx.doi.org/10.19111/bulletinmre.305201
} 
al., 2004, 2006) and (4) defining evidential weights without using expert judgments and without using location of known mineral deposits (Yousefi and Carranza, 2015). So, because the last method do not use location of known mineral deposits and expert judgments directly for weighting geological features, it is better to categorize it as an individual approach.

AHP has been used for weight calculating in mineral potential mapping as a result of the advantages for weight calculation procedures based on a pairwise comparison (Pazand et al., 2011). Among MCDM methods, the most popular ones are index overlayand technique for order preference by similarity to ideal solution (TOPSIS) (Dağdeviren et al., 2009; Noori et al., 2011). In the index overlay method each of the input maps is allocated a weight as well as all classes and spatial units existing in each factor map based on its relative importance in conjunction with expert opinion. In other words, the different classes on a single map have different weights (Pirmoradi et al. 2012). TOPSIS is based on the concept that the ideal alternative has the best level for all attributes, whereas the negative ideal is the one with all the worst attribute values (Önüt and Soner, 2008). The TOPSIS is a good method for potential mapping but this method has been used rarely for mineral potential mapping. It seems, index overlay is preferred more than TOPSIS for mineral potential mapping. In this paper we investigate the result of calcic iron skarn potential mapping in Sarvian area generated by index overlay and TOPSIS methods (based on AHP weight). The Sarvian area has been studied before because of its mineral potential for iron mineralization. In this area, evidences of iron mineralization including magnetite and hematite have been reported (Feizi and Mansouri, $2013 a$ ). The goal in this paper is to iron skarn potential map by index overlay and TOPSIS methods (based on AHP weight). Furthermore, the output prospective maps are evaluated as to how well they have predicted the known Fe prospects and the results of two MCDM methods are compared with each other.

\section{Materials and Methods}

\subsection{The Study Area and Geological Setting}

The Sarvian area is located within the OrumiehDokhtar magmatic arc in Central of Iran (Figure 1); This magmatic arc is the most important for metals,

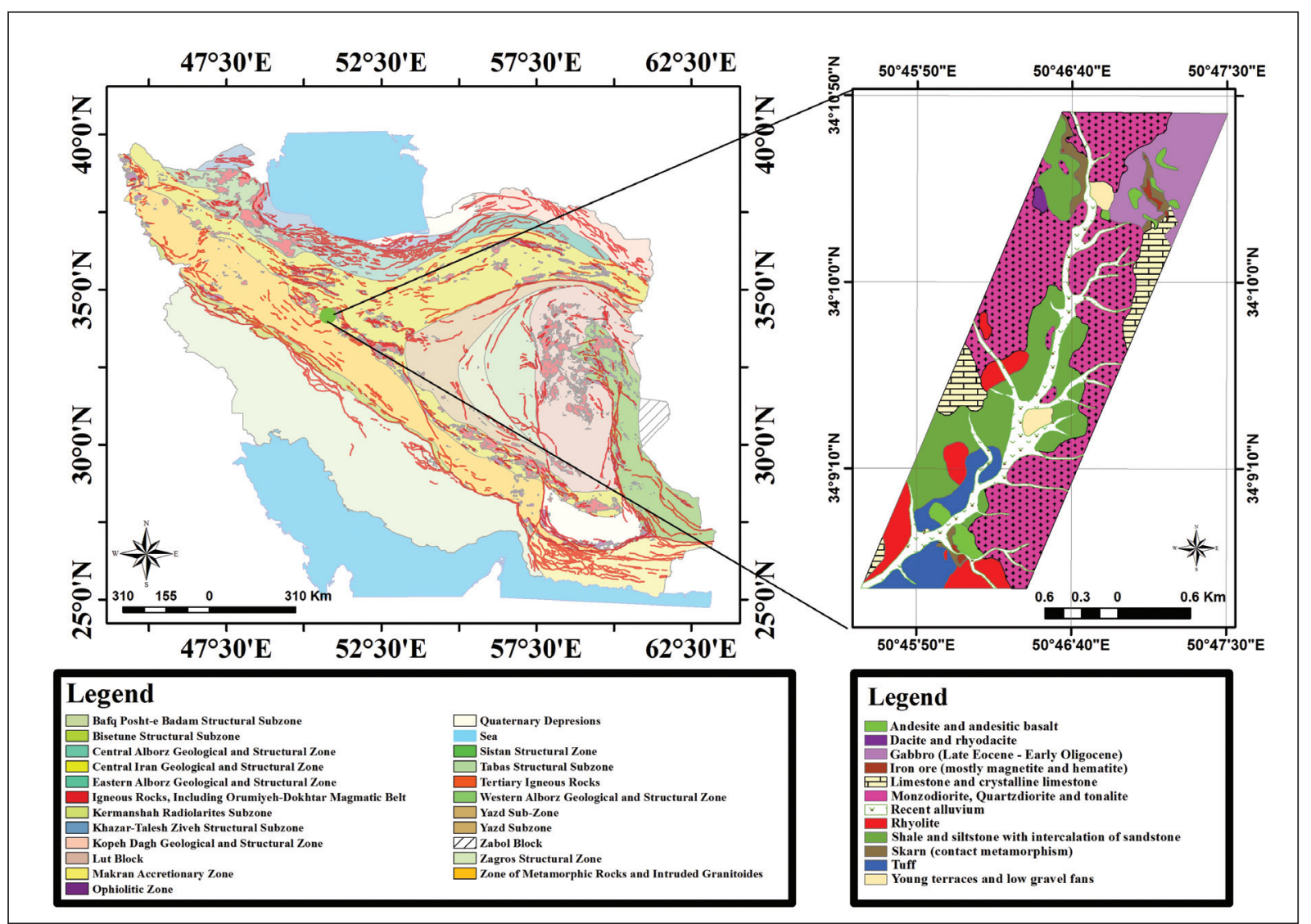

Figure 1- Physiographic-tectonic zoning map of Iran's sedimentary basins[modified from Sahandi et al. (2005)] and location of study area. 
and hosts the majority of the larger metals deposits such as copper and iron (Hassan-Nezhad and Moore, 2006). The investigated area characterized by Eocene intrusive rocks and carbonates of Qom formation. Different types of metal ore deposits, such as iron, lead and zinc, copper and distributed manganese vein and also non-metal deposits (barite) have already been documented in near the study area.

The different alteration types have been recognized are phyllic zone (muscovite, illite and quartz), argillic zone (kaolinite and montmorillonite), propylitic zone (chlorite and epidote) and iron oxide (hematite, goethite and limonite) (Feizi and Mansouri, 2012; Feizi and Mansouri, 2013a).

In addition, evidences of iron mineralization include magnetite and hematite, have been reported (Feizi and Mansouri, 2013b). Based on the existing evidences, such as contact of intrusive bodies and carbonate rocks (Qom formation) in the studied area, calcic iron skarn mineralization is suggested.

\subsection{AHP Method}

AHP is a multi-criteria decision method that uses hierarchical structures to represent a problem and then develop priorities for alternatives based on the judgment of the user (Saaty, 1980). The AHP involves the three basic steps comprising construction of a hierarchy, priority setting, and logical consistency (Macharis et al., 2004; Najafi et al., 2014). These steps are described in the following.

(1) Construction of a hierarchy: In this step the complex problem is decomposed into a hierarchical structure with decision elements (objective, attributes i.e. criterion map layer and alternatives).

(2) Priority setting: The method of deriving evidential weights via the AHP involves pairwise comparisons of criteria according to their relative importance with respect to a proposition (Carranza, 2008; Nouri et al., 2013). The pairwise judgment starts from the second level and finishes in the lowest level, alternatives. The DM uses a standardized comparison scale of nine levels that is shown in table 1 (Saaty, 2005; Dağdeviren, 2008)
Table 1- Scales for pairwise comparison (Saaty, 1980).

\begin{tabular}{|c|c|}
\hline $\begin{array}{c}\text { Preferences expressed } \\
\text { in numeric variables }\end{array}$ & $\begin{array}{c}\text { Preferences expressed in linguistic } \\
\text { variables }\end{array}$ \\
\hline 1 & Equal importance \\
\hline 3 & Moderate importance \\
\hline 5 & Strong importance \\
\hline 7 & Very strong importance \\
\hline 9 & Extreme importance \\
\hline $2,4,6,8$ & $\begin{array}{c}\text { Intermediate values between adjacent } \\
\text { scale values }\end{array}$ \\
\hline
\end{tabular}

Let $C=\{C j \mid j=1,2, \ldots, n\}$ be the set of criteria. The results of the pairwise comparison on $\mathrm{n}$ criteria can be summarized in an $(n \times n)$ evaluation matrix $A$ in which every element aij $(i, j=1,2, \ldots, n)$ is the quotient of weights of the criteria as shown in Eq. (1) (Dağdeviren, 2008; Abedi et al., 2013).

$A=\left[\begin{array}{cccc}a_{11} & a_{12} & \ldots & a_{1 n} \\ a_{21} & a_{22} & \ldots & a_{2 n} \\ \cdot & \cdot & \cdot & \cdot \\ \cdot & \cdot & \cdot & \cdot \\ a_{n 1} & a_{n 2} & . & a_{n n}\end{array}\right], a_{i i}=1, a_{1 / j i}=1, a_{j i} \neq 0$

The mathematical process commences to normalize and find the relative weights for each matrix. The relative weights are given by the right eigenvector $(w)$ corresponding to the largest eigenvalue $\left(\lambda_{\max }\right)$ asEq. (2):

$A_{W}=\lambda_{\max } W$

If the pairwise comparison are completely consistent, the matrix A has rank 1 and $\lambda_{\max }=\mathrm{n}$. In that case, weights can be obtained by normalizing any of the rows or columns of A matrix (Dağdeviren, 2008; Abedi et al., 2013).

(3) Logical consistency: The quality of the output of the AHP is strictly related to the consistency of the pairwise comparison judgments. The consistency is defined by the relation between the entries of $\mathrm{A}$ as followEq. (3):

$a_{i j} \times a_{j k}=a_{i k}$

When the pairwise comparison matrices are completely consistent, the priority (or weight) vector corresponds to the right eigenvector $(w)$. Therefore, the highest eigenvalue $\left(\lambda_{\text {max }}\right)$ is equal to $n$. In case the inconsistency of the pairwise comparison matrices is limited, slightly $\lambda_{\max }$ deviates from $\mathrm{n}$.This deviation $\left(\lambda_{\max }-n\right)$ is used as a measure for inconsistency. This measure that is divided by $(n-1)$ yields the average of 
the other eigenvectors Eq. (4)(Macharis et al., 2004).

The consistency index $(\mathrm{CI})$ is:

$C I=\frac{\lambda_{\max }-n}{n-1}$

The final consistency ratio (CR), on the basis of which one can conclude whether the evaluations are sufficiently consistent, is calculated as the ratio of the $\mathrm{CI}$ and therandom index (RI is given in table 2) and it corresponds to the degree of consistency that automatically arises when completing at random reciprocal matrices with the values on the 1-9 scale Eq. (5) (Macharis et al., 2004):

$C R=\frac{C I}{R I}$

The number 0.1 is the accepted upper limit for $\mathrm{CR}$. If the final $\mathrm{CR}$ exceeds this value, the evaluation procedure has to be repeated to improve consistency. The measurement of consistency can be used to evaluate the consistency of DMs as well as the consistency of all the hierarchy (Dağdeviren, 2008).

Table 2- Some random inconsistency indices (RI) generated by Saaty (1977).

\begin{tabular}{|c|c|c|c|c|c|c|c|c|c|c|}
\hline $\mathrm{n}$ & 1 & 2 & 3 & 4 & 5 & 6 & 7 & 8 & 9 & 10 \\
\hline $\mathrm{RI}$ & 0 & 0 & 0.58 & 0.9 & 1.12 & 1.24 & 1.32 & 1.41 & 1.45 & 1.49 \\
\hline
\end{tabular}

\subsection{Index Overlay Method}

This method is known as a knowledge-based method. In the early steps of exploratory operations (especially in areas with minimum information) Knowledge-based methods are suggested. These methods are used in areas where there are no known resources orwhere resources are scarce (Green Fields) (Carranza, 2008; Yousefi and KmkarRouhani, 2010).

In this method each map consists of various classes to which different values have been assigned; these values are multiplied by the pertinent weight, and the average score of each item (polygon or pixel) is computed. Then, these scores are added to the maps and combined. Finally, they are normalized by the sum of the weights. This method follows the general form bellow Eq. (6) (Malczewski, 2006):

$\mathrm{S}=\left(\sum_{i}^{n} \operatorname{Sij} \mathrm{Wi}\right) /\left(\sum_{i}^{n} \mathrm{Wi}\right)$

Where $\mathrm{S}$ denotes a weighted score for each condition Wi is the weight of $i^{\text {th }}$ input map, $S_{i j}$ show rating $\mathrm{j}^{\text {th }}$ class is the class of the $\mathrm{i}^{\text {th }}$ that are rated and weighted (Malczewski, 2006).

\subsection{TOPSIS Method}

The TOPSIS (technique for order preference by similarity to an ideal solution) method was first introduced by Hwang and Yoon (1981). The basic principle is that the best alternative should have the shortest distance from the ideal solution (also called the positive ideal solution) and the farthest distance from the negative ideal solution (also called the antiideal solution).

The TOPSIS procedure consists of the following steps (Dağdeviren et al., 2009):

(1) Create a decision matrix. This decision matrix can be establish as follows Eq. (7):

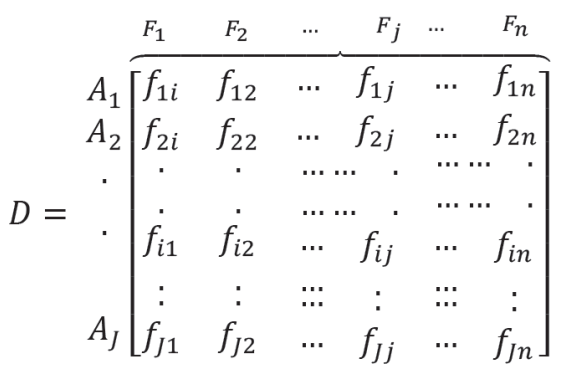

(2) Calculate the normalized decision matrix. The normalized value is calculated as

$$
r_{i j}=f_{i j} / \sqrt{\sum_{j=1}^{j} f_{i j}^{2}}, j=1, \ldots J ; i=1, \ldots, n
$$

(3) Calculate the weighted normalized decision matrix. The weighted normalized value is calculated as

$v_{i j}=w_{i j} r_{i j}, j=1, \ldots J ; i=1, \ldots, n$

Where is the weight of the th attribute or criterion and $\sum_{i=1}^{n} w_{i}=1$.

(4) Determine the ideal and negative-ideal solution.

$A^{+}=\left\{v_{1}^{+}, \ldots, v_{n}^{+}\right\}=\left\{\left(\max _{i j} \mid i \in I^{\prime}\right),\left(\operatorname{minv}_{i j} \mid i \in I^{\prime \prime}\right)\right\}$,

$A^{-}=\left\{v_{1}^{-}, \ldots, v_{n}^{-}\right\}=\left\{\left(\operatorname{minv}_{i j} \mid i \in I^{\prime}\right),\left(\max _{i j} \mid i \in I^{\prime \prime}\right)\right\}$

Where is associated with benefit criteria, and is associated with cost criteria.

(5) The separation of each alternative from the positive-ideal solution () is given as

$D_{j}^{+}=\sqrt{\sum_{i=1}^{n}\left(v_{i j}-v_{i}^{+}\right)^{2}} \quad j=1,2, \ldots, J$ 
Also, The separation of each alternative from the negative-ideal solution () is given as

$D_{j}^{-}=\sqrt{\sum_{i=1}^{n}\left(v_{i j}-v_{i}^{-}\right)^{2}} \quad j=1,2, \ldots, J$

(6)Calculate the relative closeness to the ideal solution and rank the performance order.

$C C_{j}^{+}=\frac{D_{j}^{-}}{D_{j}^{+}+D_{J}^{-}} j=1,2, \ldots, J ; C C_{j}^{+} \in[0,1]$

The larger the index value, the better the performance of the alternatives.

\subsection{Calcic Iron Skarn (CIS) Deposits Model}

The iron skarn deposits are significant and important for their high content of magnetite and minor amounts of $\mathrm{Ni}, \mathrm{Co}, \mathrm{Cu}$ and $\mathrm{Au}$. Most of iron skarns are comprised of magnetite with only minor silicate gangue. The iron skarn deposits are very large ( $>500$ million tons, with $>300$ million tons contained $\mathrm{Fe}$ ) (Vidal et al., 1990). In oceanic island arcs, calcic iron skarns (CIS) are formed with iron-rich plutons intruded into volcanic wall rocks and limestone. Skarn minerals all are iron rich and generally include pyroxene and garnet, and small amount of actinolite, ilvaite and epidote (Purtov et al., 1989).Except CIS, magnesian iron skarns (MIS) that forms from ironrich plutons intruded dolomitic wall, do not contain much iron. Russian deposits have more outcrops of CIS deposits against MIS (Sokolov and Grigorev, 1977).

\subsection{Criteria Description and Application}

In this paper, geological, geochemical and geophysical evidential data are selected considering the experiences reached from previous experiments of CIS deposit exploration in the study area (Feizi and Mansouri, 2012; Feizi and Mansouri, 2013b). The mentioned evidential layers (geological, geochemical and geophysical) are the most important layers for MPM which were utilized numerous (Abedi and Norouzi, 2012; Abedi et al., 2012a; Abedi et al., 2012b; Abedi et al., 2012c; Najafi et al., 2014). The main causes of using these layers are, availability and usefulness for MPM. For this based on the experiences, above description of deposit model of the deposit type mineralization, we used following evidential layers as the most principal regional scale criteria for prospecting CIS deposit in the study area; lithology of intrusive rocks as heat sources and host rock lithology (based on 1:5000 geology map of the study area), ores and minerals (based on geological evidences), lithogeochemical anomalies (interpreted from analyses of rock samples taken from outcropping rocks that extended in the study area), and magnetic anomaly (based on ground magnetic data analyses).

For obtaining the evidential layers of intrusive rocks as heat sources and host rocks lithology, these layers, were generated from the 1:5000 geological map of the study area. In this paper tonalite, quartzdiorite, monzodiorite and gabbro were presented as heat sources lithology. In addition, skarn unit (contact metamorphism) and limestone and crystalline limestone of Qom formation were introduced as host rocks lithology.

Ores and minerals which are significant in CIS mineralization, were extracted by remote sensing and confirmed with check field and geological evidences. To separate ores and minerals; Spectral Angel Mapper (SAM) and Band Ratio techniques have been applied on ASTER data (Nouri et al., 2012; Feizi and Mansouri, 2012). Magnetite, pyrite, hematite, calcite, pyroxene and garnet were manifested as important ores and minerals in CIS deposit.

Also, lithogeochemical anomalies interpreted from the results of analyzing rock samples taken from outcropping rocks in the study area. In this area, the element content of $\mathrm{Fe}, \mathrm{Cu}, \mathrm{Zn}, \mathrm{Au}$ and $\mathrm{As}$ in the samples were used as indicators for CIS deposits.

Ground geophysical magnetic data were used to define magnetic anomaly respectively with reductionto-the-pole (RTP) technique (Mansouri et al. 2015). The RTP technique transforms total-magneticintensity (TMI) anomalies to anomalies that would be measured if the field were vertical (assuming there is only an inducing field). This RTP transformation makes the shape of magnetic anomalies more closely related to the spatial location of the source structure.

After that, for informing the classes relative importance, they must be specified with weights (Bonham-Carter, 1994; Carranza, 2008). Hence, the classes of processed maps were determined with scores within $[1,10]$ range (Table 3 ) (Porwal et al., 2004; Porwal et al., 2006). The generated weighted evidence layers were utilized for MPM of CIS deposit in the Sarvian prospecting area, have been demonstrated in figure 2. Furthermore, all pixel values of all evidential layers were normalized 
Table 3- Summary of evidence maps, classes and their corresponding weights for skarn mineralization.

\begin{tabular}{|c|c|c|c|}
\hline Data & Evidential layer & Class & Class score \\
\hline \multirow{9}{*}{ Geological data } & Heat source & Tonalite- Quartdiorite & 10 \\
\hline & \multirow{2}{*}{ Host rock } & Skarn & 10 \\
\hline & & Limestone and crystalline limestone & 9 \\
\hline & \multirow{6}{*}{ Ores and minerals } & Magnetite & 10 \\
\hline & & Pyrite & 8 \\
\hline & & Hematite & 8 \\
\hline & & Garnet & 6 \\
\hline & & Pyroxene & 4 \\
\hline & & Calcite & 2 \\
\hline \multirow{5}{*}{ Geochemical data } & \multirow{5}{*}{ Lithogeochemical sample } & Rock sample anomaly, Fe & 10 \\
\hline & & Rock sample anomaly, $\mathrm{Cu}$ & 6 \\
\hline & & Rock sample anomaly, Zn & 4 \\
\hline & & Rock sample anomaly, $\mathrm{Au}$ & 2 \\
\hline & & Rock sample anomaly, As & 2 \\
\hline Geophysical data & Ground magnetic & Magnetic anomaly & 10 \\
\hline
\end{tabular}

between ranges of 0 to 1 with the same pixel or cell size.

\subsection{Application of the AHP Method to CIS Deposit Potential Mapping}

CIS potential mapping using AHP method consists of the following steps (Pazand et al., 2011):

1. The hierarchical structure which is used to generate MPM in this study is illustrated in figure 3.

2. A pairwise comparison method (Saaty, 1980) was used for computing relative importance weights for criteria. Each layer was compared in pairwise comparisons related to each of the elements at the level directly above.

3. Analyzing the relationship of each index caused establishing the level of the structure.

4. All of the weights determined by the pairwise comparison matrix (PCM).

Criteria and sub criteria were ranked by using table 1.A group of specialists in the study of skarn deposits determined and decided the relative importance of each factor for mineralization, then all the opinions have been analysed, and finally, the rank of relative importance have been gained for each factors as shown in table 1 . The tree diagram with three main criteria (geological, geochemical and geophysical data layers) and five sub criteria (heat source, host rock, ores and indications, geochemical anomaly, geophysical anomaly), was used for determination of each factor weight (Figure. 3). It should be noted also all pixels in final prospecting map are alternatives. By normalizing the weight of each factor, $\mathrm{W}_{\mathrm{i}}$ is calculated. $\mathrm{W}_{\mathrm{i}}$ is criteria weight. It is mentioned that the $\mathrm{CR}$ values of all the comparisons were lower than 0.1 . The $\mathrm{CR}$ with range lower than 0.1 shows that the use of the weights was appropriate (Saaty, 1977).

Based on the results of pairwise comparison matrix (PCM), weights of sub criterias for geological data, including heat source, host rock, ores and minerals were calculated (Table 4). It is apparent that other weights of sub criterias (including geochemical anomaly and geophysical anomaly) were placed equivalent to 1 , because with one sub criteria the PCM cannot be formed. With the results of tables 3 and 4, the main criteria including geological, geochemical and geophysical data, were used to calculate the final matrix. In this way the criteria importance coefficients were calculated. The PCM of table 5 was created based on expert opinion with accepted CR. For instance, the procedure of obtaining normalized weights from evaluation matrix with respect to geological data alternatives is illustrated. For this goal, firstly the total rows of each criterion was calculated. This number is then divided by the total of the row criteria sum. For example (based on table 5) the total row of geological data was $(1+5+3)=9$. Also this number was 1.45 and 5.33 for geochemical data and geophysical 


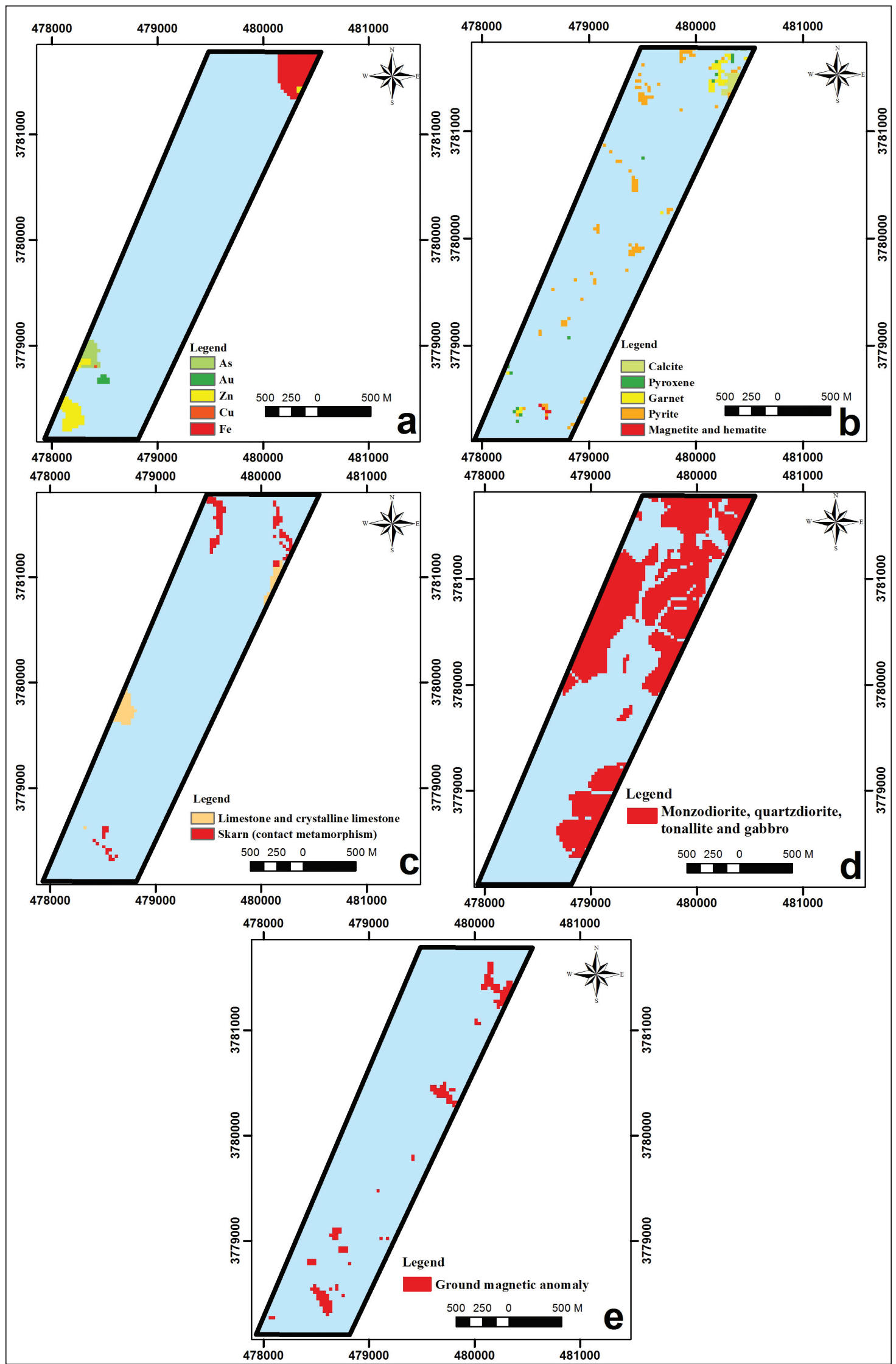

Figure 2- Derived geo-evidential layers for skarn mineralization used in index overlay and TOPSIS prospectivity mapping. 


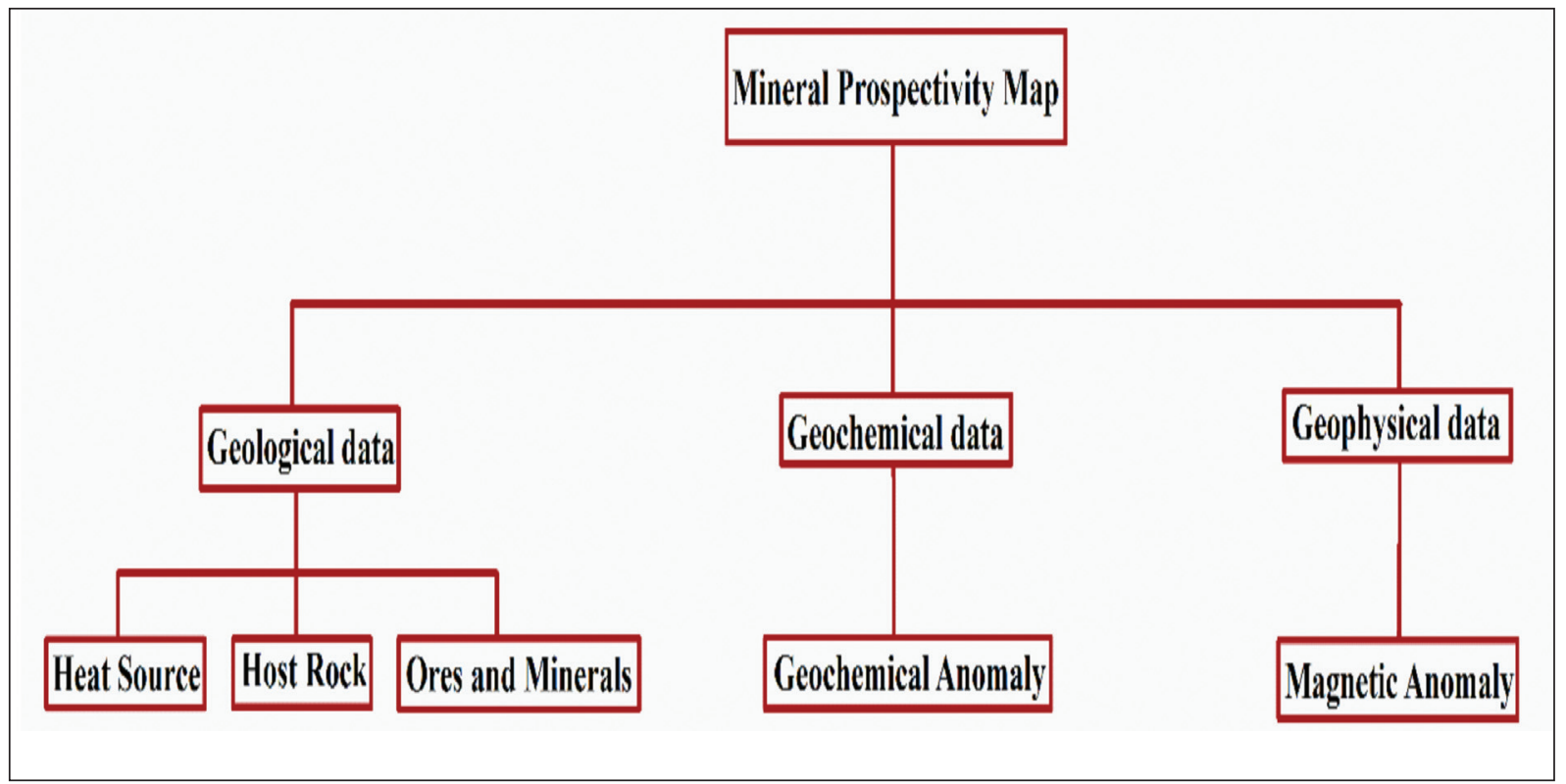

Figure 3- Hierarchy used for prospectivity mapping.

data respectively. Then, the total of the row criteria sum was $(9+1.45+5.33=15.78)$. Finally, for weight calculating of each criterion, the total rows of each criterion was divided by the total of the row criteria sum. For example the weight of geological data was $(9 / 15.78=0.57)($ Table 5$)$. Also this number was 0.090 and 0.338 for geochemical data and geophysical data respectively (Table 5).

In table 5 , the consistency ratio is $\mathrm{CR}=0.0726$ which is suitable $(\mathrm{CR}<1)$. Geological data in table 5 is the most important factor $(\mathrm{W}=0.570)$. The next most important factor is geophysical data $(\mathrm{W}=0.338)$, followed by geochemical data $(\mathrm{W}=0.090)$.

Table 4- Weights of sub criteria for geological data.

\begin{tabular}{|c|c|c|c|c|}
\hline $\mathrm{CR}=0.0405$ & $\begin{array}{c}\text { Heat } \\
\text { source }\end{array}$ & $\begin{array}{c}\text { Ores and } \\
\text { Minerals }\end{array}$ & $\begin{array}{c}\text { Host } \\
\text { rock }\end{array}$ & $\mathrm{W}$ \\
\hline Heat source & 1.000 & 3.000 & 5.000 & 0.370 \\
\hline Ores and Minerals & 0.333 & 1.000 & 3.000 & 0.137 \\
\hline Host rock & 0.200 & 0.333 & 1.000 & 0.493 \\
\hline
\end{tabular}

Table 5- Weights of main criteria.

\begin{tabular}{|c|c|c|c|c|}
\hline $\mathrm{CR}=0.0726$ & $\begin{array}{c}\text { Geological } \\
\text { data }\end{array}$ & $\begin{array}{c}\text { Geochemical } \\
\text { data }\end{array}$ & $\begin{array}{c}\text { Geophysical } \\
\text { data }\end{array}$ & $\mathrm{W}$ \\
\hline $\begin{array}{c}\text { Geological } \\
\text { data }\end{array}$ & 1.000 & 5.000 & 3.000 & 0.570 \\
\hline $\begin{array}{c}\text { Geochemical } \\
\text { data }\end{array}$ & 0.2 & 1.000 & 0.25 & 0.090 \\
\hline $\begin{array}{c}\text { Geophysical } \\
\text { data }\end{array}$ & 0.33 & 4.00 & 1.000 & 0.338 \\
\hline
\end{tabular}

2.8. Application of the Index Overlay Method to CIS Deposit Potential Mapping

Based on the calculated weights by AHP method, index overlay method is used in this study via Eq. 15 .

Result $=\sum_{j=1}^{n} \sum_{i=1}^{m} W_{j} W_{i}$

Where $W_{j}$ is the importance weight of the jth criteria, and $\mathrm{W}_{\mathrm{i}}$ is the preferred weight of the ith alternatives. In this method every layer, according to the values of their units, is given various classes. Additionally, every layer has an especial weight based on studies and expert opinion. After processing, the potential target map of iron is prepared using the Index Overlay method (Figure 4).

\subsection{Application of the TOPSIS Method to CIS Deposit Potential Mapping}

Application of the TOPSIS procedure for mineral potential mapping was proposed by Pazand et al. (2012). As it was explained each of the evidence maps has been converted to raster with specific cell size. So the final matrix should be with 10913 row (Aj) cells and 5 columns (Fn) (heat source, ores and minerals, host rocks, lithogeochemical anomaly, ground magnetic anomaly) was formed as explained in formula. 6. Hence, there are 5 evidential maps (each map include 10913 cells with unique values). Also each cell has unique geographical coordinates. First of all we convert each cell to a unique value with a 


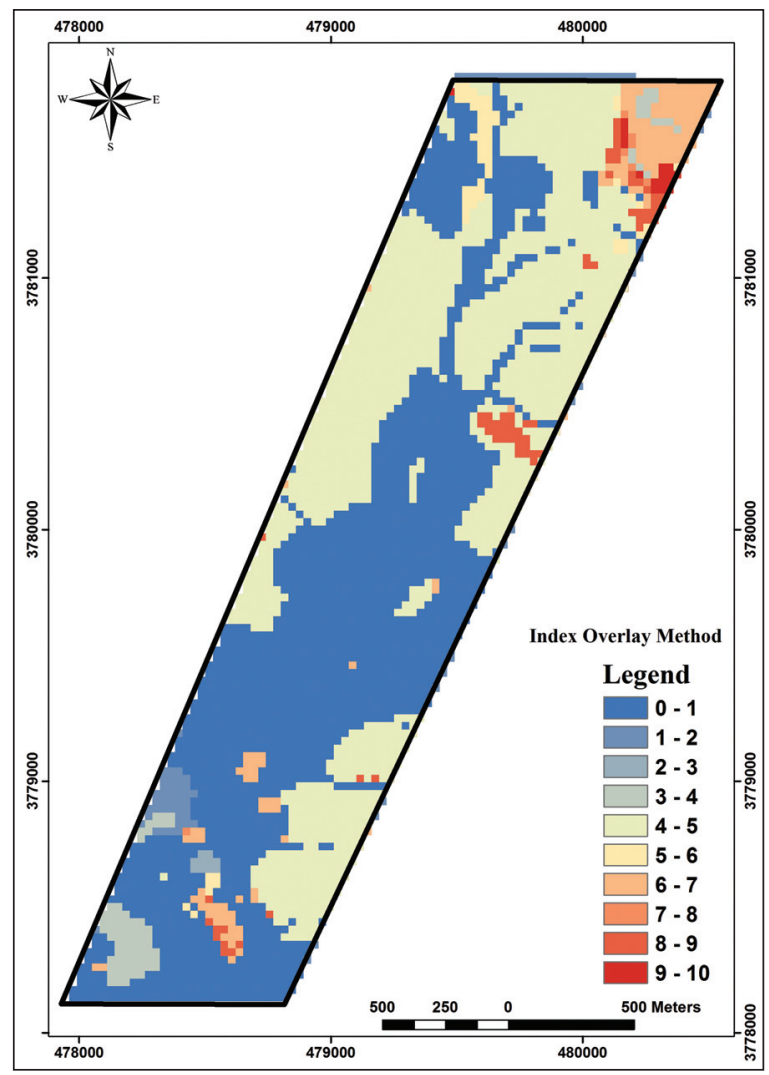

Figure 4- The final prospectivity map for Skarn deposit by index overlay method.

unique geographical coordinates. In this way the final matrix is generated.

For running the TOPSIS procedure, ranks of relative importance for each criterion should be determined. In this research, we used the same criteria weights (in AHP method) which is evaluated in table 6. It is obvious that calculating the final weight is created by, multiplying the weight of each criterion to alternatives. For example this number was calculated for Heat source by multiplying 0.570 (Geological data weight which was calculated in table 5) to 0.370 (Heat source initial weight which was calculated in table 4). So, the final weight was $0.078,0.281,0.092$ and 0.338 for Ores and minerals, Host rocks, Lithogeochemical anomaly and Ground magnetic anomaly respectively (Table 6). After that the TOPSIS procedure runs in Matlab software. Hence, values of the alternatives has been determined. Thus, for each alternative (each cell), there is a unique value which is the result of TOPSIS method for each cell.
Table 6- Weight of each criterion and alternative to evaluate Skarnprospectivity map.

\begin{tabular}{|c|c|c|c|c|}
\hline Criterion & Weight & Alternative & Weight & $\begin{array}{c}\text { Final } \\
\text { Weight }\end{array}$ \\
\hline \multirow{2}{*}{$\begin{array}{c}\text { Geological } \\
\text { data }\end{array}$} & 0.570 & Heat source & 0.370 & 0.211 \\
\cline { 3 - 5 } & Ores and minerals & 0.137 & 0.078 \\
\cline { 3 - 5 } & 0.092 & $\begin{array}{c}\text { Lithogeochemical } \\
\text { anomaly }\end{array}$ & 1 & 0.493 \\
\hline $\begin{array}{c}\text { Geochemical } \\
\text { data }\end{array}$ & 0.338 & $\begin{array}{c}\text { Ground magnetic } \\
\text { anomaly }\end{array}$ & 1 & 0.281 \\
\hline $\begin{array}{c}\text { Geophysical } \\
\text { data }\end{array}$ & \multicolumn{4}{|c}{} \\
\hline
\end{tabular}

At last, the final prospectivity mapfor CIS deposit is plotted by specific grid cell size. In this way the mapping of potential for CIS deposit mineralization in the Sarvian area, was prepared by Matlab and plot by ArcGIS software (Figure 5).

\section{Discussion}

The legend of final prospecting maps for Skarn deposit by index overlay and TOPSIS methods (based on AHP weight) was specified by dividing the prospectivity values into 10 classes for better comparison (Figure 4 and Figure 5). It is obvious that

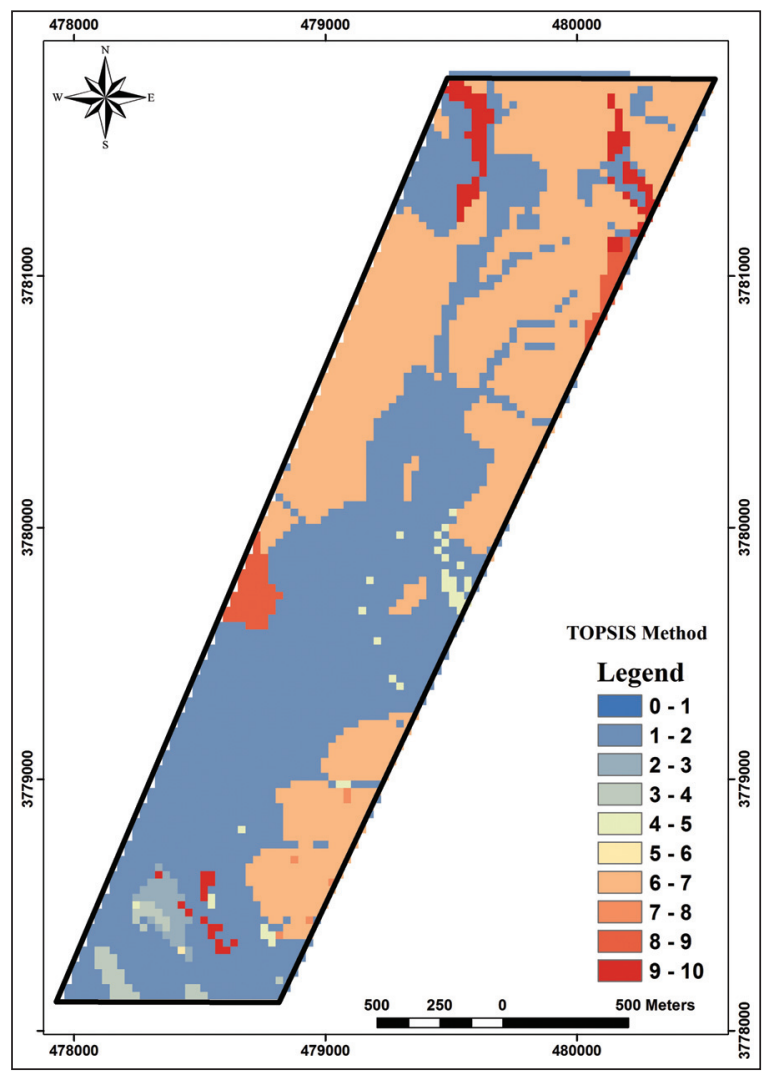

Figure 5 - The final prospectivity map for Skarn deposit by TOPSIS method. 
each class has a priority for exploration. For instance, for Index Overlay and TOPSIS final prospectivity maps, the first class (range of $0-1$ ) has the lowest exploratory priority and the last class (range of $9-$ 10) has the highest (Table 7). It is obvious that there are some differences between the results of each method.The comparative analyses of index overlay and TOPSIS integration models, has been performed by selecting four Ground Control Points (GCPs) for check field (Figure 6). Based on table 7 classification, the class number of GCPs in the study area, are specified in table 8 .

Table 7- Classification of data values in final prospectivity maps.

\begin{tabular}{|c|c|}
\hline Class number & The exploratory priority \\
\hline 1 & The lowest \\
\hline 2 & \multirow{8}{*}{$\begin{array}{c}\text { Intermediate exploratory priority } \\
\text { between the lowest and highest } \\
\text { precedence }\end{array}$} \\
\hline 3 & \\
\hline 4 & \\
\hline 5 & \\
\hline 6 & \\
\hline 7 & \\
\hline 8 & \\
\hline 9 & \\
\hline 10 & The highest \\
\hline
\end{tabular}

Table 8- The class numbers of GCPs in the Sarvian area.

\begin{tabular}{|c|c|c|}
\hline \multirow{2}{*}{ GCP } & \multicolumn{2}{|c|}{ Class number } \\
\cline { 2 - 3 } & Index Overlay & TOPSIS \\
\hline 1 & 10 & 10 \\
\hline 2 & 5 & 10 \\
\hline 3 & 6 & 10 \\
\hline 4 & 9 & 6 \\
\hline
\end{tabular}

In GCP1, four geological units were observed. The first unit contains shale and siltstone with intercalation of sandstone (with geological age of jurassic). In this unit, contact of intrusive bodies with shale and siltstone, caused contact metamorphism and hornfels creation; the second unit is Oligo-Miocene limestone; the third unit contains semi-basic intrusive rocks, such as diorite, monzonite and andesitic dykes; and the fourth geological unit contains skarn units and iron ore mineralization. The collision between intrusive rocks and limestone units causes the iron skarn mineralization, which is obvious in Figure 7a and $7 \mathrm{~b}$ shows a polished section from GCP1 which contains magnetite and ilmenite. The magnetite is the most abundant ore of this unit (almost 90\% of the rock volume). Also secondary replacement ofhematite and ilmenite are obvious in mentioned polished section. Figure $7 \mathrm{c}$ shows a thin section

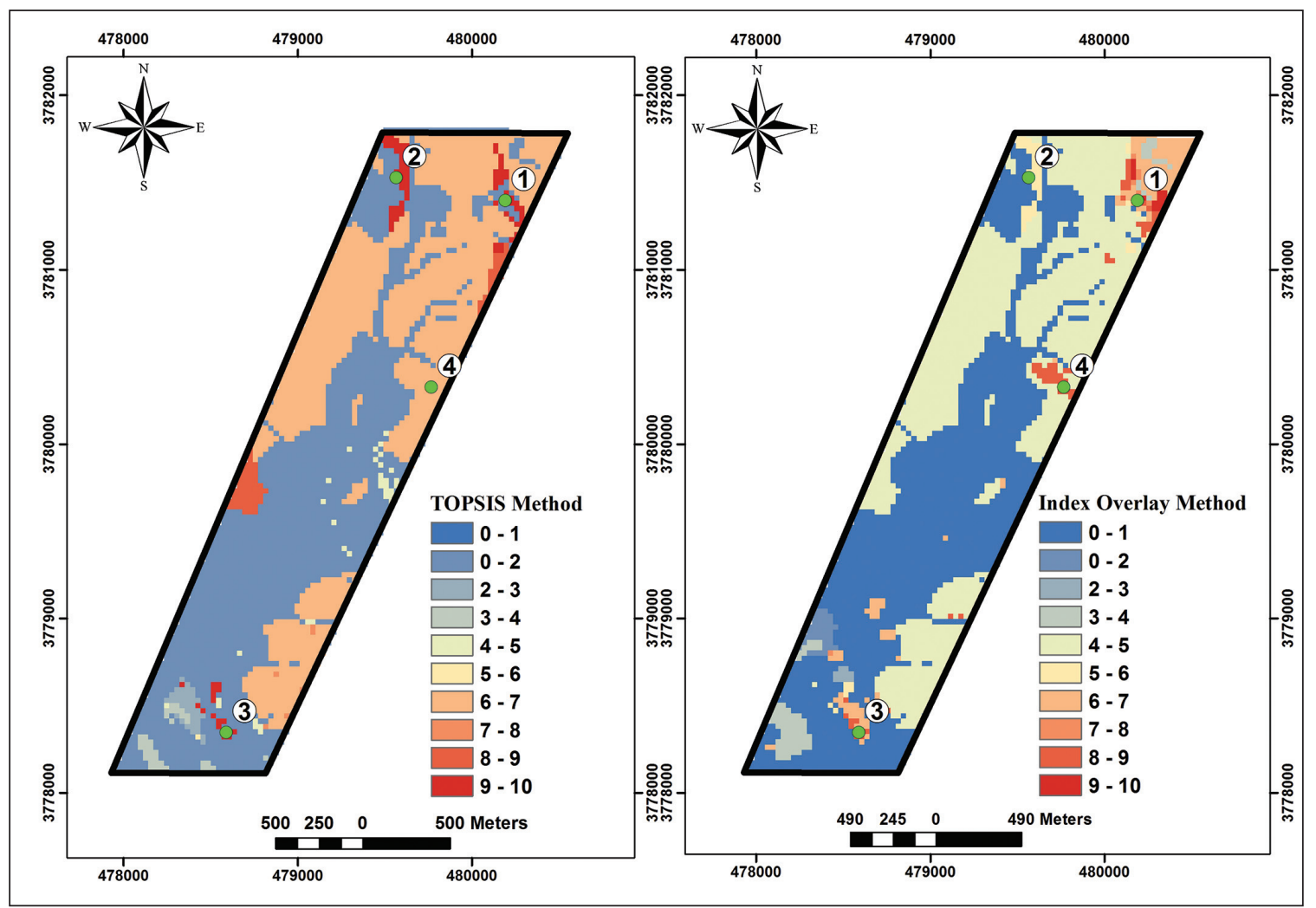

Figure 6- The comparative analyses of index overlay and TOPSIS integration models, with four GCPsfor check field. 


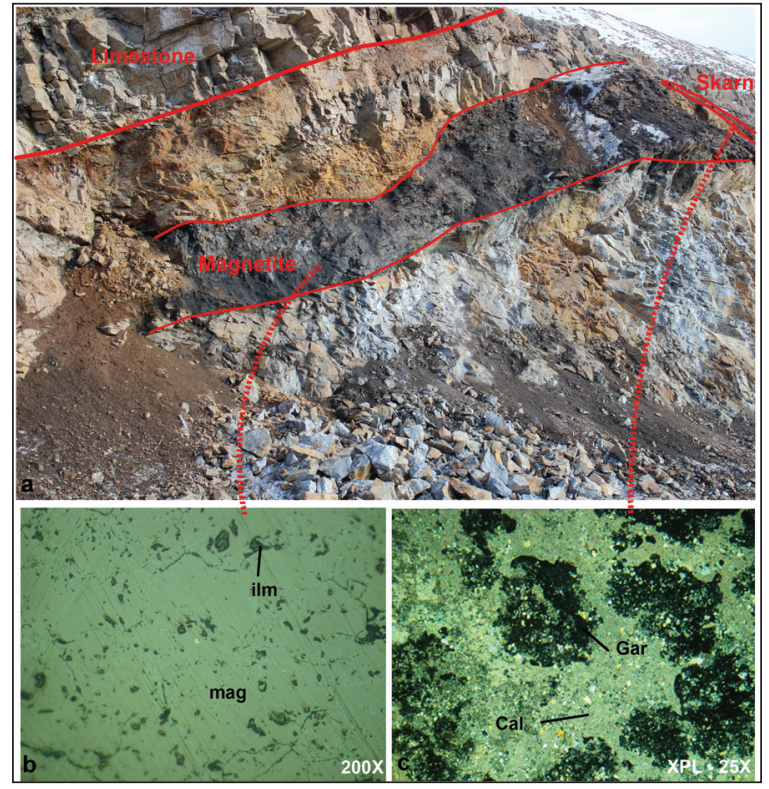

Figure 7- GCP1. a) Contains magnetite, intrusive rocks, limestone and skarn unit (contact metamorphism). b) Magnetite and ilmenite is obvious in prepared polished section from ore body. c) Thin section with granoblastic texture, contains calcite, garnet, tremolite, wollastonite and idocrase from skarn unit.

with granoblastic texture, contains calcite, garnet, tremolite, wollastonite and idocrase. This section prepared from host rock of magnetite mineralization. Thus, the skarn mineralization was observed in GCP1. In GCP1, the value of index overlay and TOPSIS prospectivity maps are the same and have the highest priority (class10) (Table 8 ).

In GCP2, contact of intrusive bodies with sedimentary units, caused contact metamorphism and hornfels creation. The most important skarn mineralization in GCP2 is magnetite. Also garnet has outcrop near iron mineralization. The hematite is obvious in mentioned GCP as a secondary mineral. In Figure $8 \mathrm{a}$, contact of intrusive bodies with limestone causes iron skarnmineralization obviously. Figure $8 \mathrm{~b}$ shows a thin section,mainly contains wollastonite, garnet, calcite and chlorite. Diopside and garnet are the most abundant minerals in mentioned section. In GCP2, the value of index overlay prospectivity is five and TOPSIS is ten (Table 8). So, according to the observed iron mineralization in GCP2, high accuracy of TOPSIS method in comparison with the index overlay was revealed.

In GCP3, magnetite is the most important skarn mineralization (Figure 9). The pyrite is obvious in iron
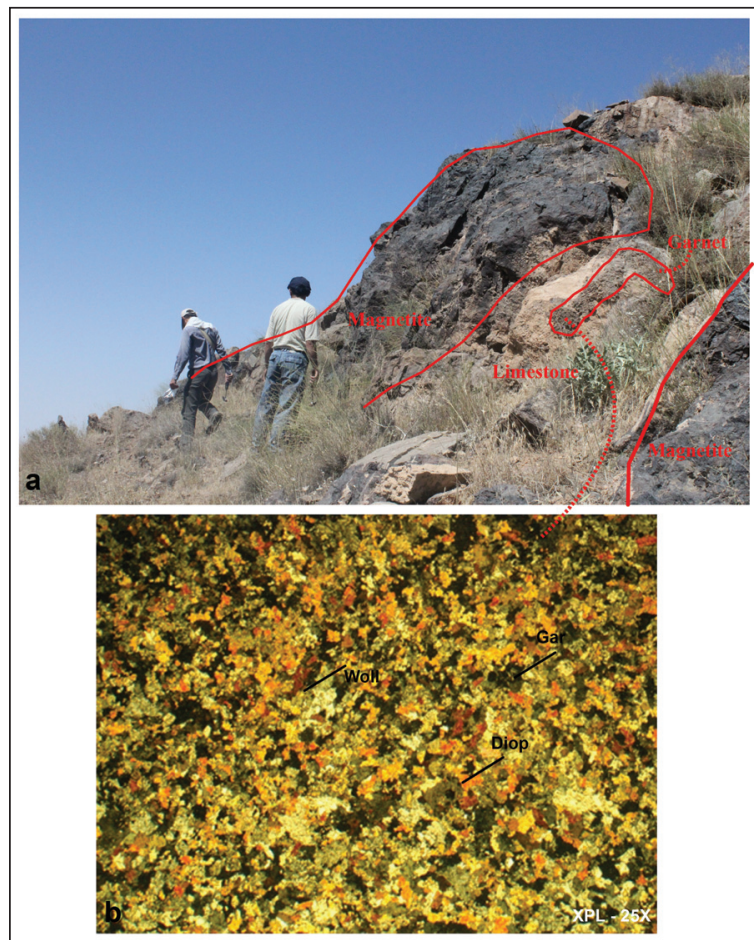

Figure 8- GCP2. a) Contact of intrusive rocks with limestone causes iron skarn mineralization. b) Thin section contains diopside,wollastonite, garnet, calcite and chlorite.

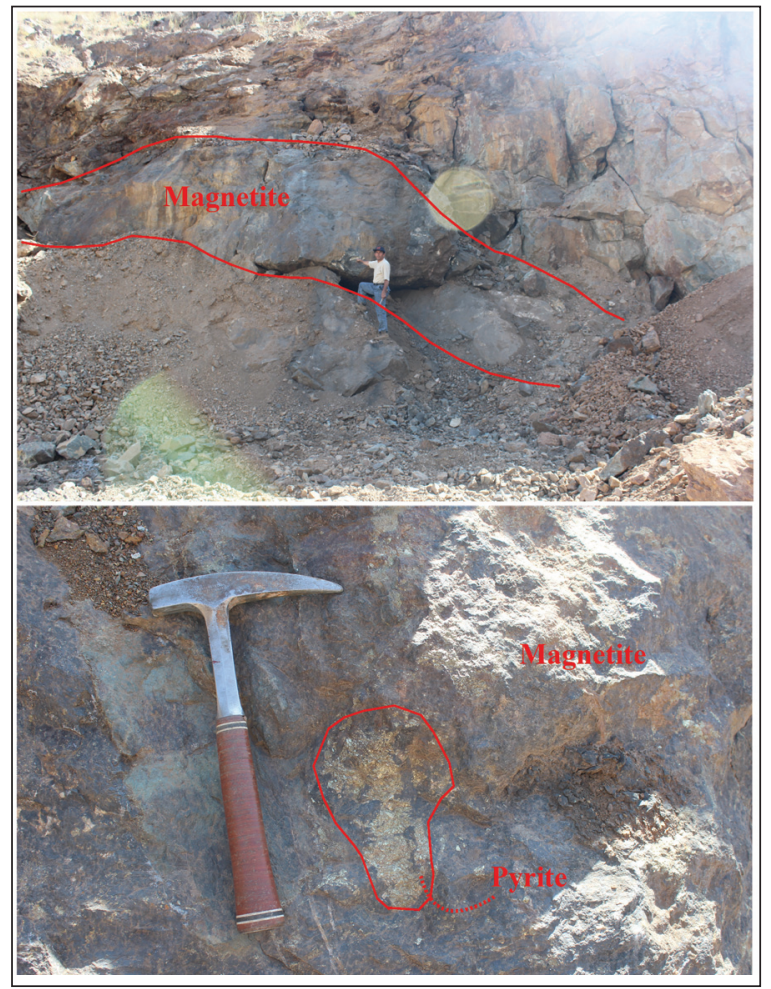

Figure 9- GCP3. a) Magnetite ore body. b) The pyrite mineralization in magnetite. 
mineralization in figure 9. The skarn unit is the host rock of iron mineralization and the intrusive rocks haven't any outcrop in mentioned GCP. According to the ground geophysical studies, it seems the intrusive bodies are in the further depth. In GCP3, the value of index overlay prospectivity is six and TOPSIS is ten (Table 8). Thus, based on the observed iron mineralization in GCP3, high accuracy of TOPSIS method in comparison with the index overlay was confirmed.

In GCP4, the outcrop of limestone without any mineralization is obvious in figure 10. In GCP4, the value of index overlay prospectivity is nine and TOPSIS is six (Table 8). In the other words, index overlay method predicts higher exploratory priority against TOPSIS approach for GCP4, wrongly. Thus in GCP4, high accuracy of TOPSIS method in comparison with the index overlay was approved again.

\section{Conclusion}

Exploration strategies for non-renewable resources have been changing rapidly along with the accelerating innovations in computer hardware and informationprocessing technology. The aim of this research is to compare index overlay and TOPSIS (based on AHP weight) model for predictive skarn potential map. In this paper, for Calcic Iron Skarn mineralization, criteria and subcriteria introduced and ranked for generating mineral prospectivity map. Each class had a priority for exploration. It was obvious that there are some differences between the results of each method. The comparative analyses of index overlay and TOPSIS

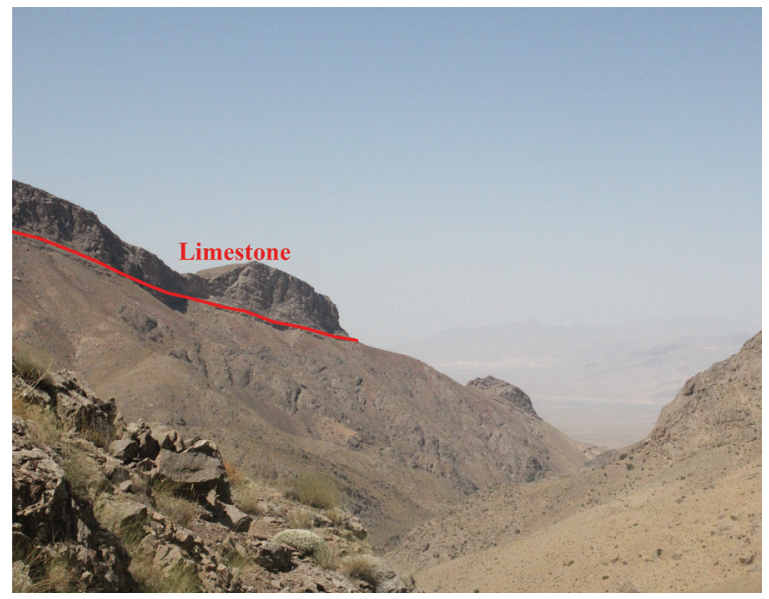

Figure 10- GCP4. The outcrop of limestone without any mineralization. (based on AHP weight) integration models, has been performed by selecting four GCPs for check field.

In GCP 1, 2 and 3, contact of intrusive bodies with sedimentary units, caused contact metamorphism and iron ore mineralization but in In GCP4, The outcrop of limestone without any mineralization was obvious in surface, although high magnetic anomaly (based on ground magnetic data analyses) is distinct. The field study in Sarvian area shows that, separation anomaly has done better and more accurate in TOPSIS method against index overlay approaches. Thus, for reconnaissance of Calcic Iron Skarn in Sarvian area and near prospecting area the TOPSIS method is introduced in comparison with index overlay method.

\section{Acknowledgement}

The authors would like to thank Amir Abbas Karbalaei Ramezanali for his helpful suggestions for improving this paper.

\section{References}

Abedi, M., Norouzi, G. H., 2012. Integration of various geophysical data with geological and geochemical data to determine additional drilling for copper exploration. Journal of Applied Geophysics, 83, 35-45.

Abedi, M., Norouzi, G. H., Bahroudi, A. 2012a. Support vector machine for multi-classification of mineral prospectivity areas. Computers \& Geosciences, 46, 272-283.

Abedi, M., Torabi, S. A., Norouzi, G. H., Hamzeh, M., Elyasi, G. R. 2012b. PROMETHEE II: a knowledgedriven method for copper exploration. Computers \& Geosciences, 46, 255-263.

Abedi, M., Torabi, S. A., Norouzi, G. H., Hamzeh, M. 2012c. ELECTRE III: A knowledge-driven method for integration of geophysical data with geological and geochemical data in mineral prospectivity mapping. Journal of applied geophysics, 87, 9-18.

Abedi, M., Torabi, S. A., Norouzi, G. H. 2013. Application of fuzzy AHP method to integrate geophysical data in a prospect scale, a case study: Seridune copper deposit. Bollettino di GeofisicaTeoricaedApplicata, 54, 145-164.

Bonham-Carter, G.F. 1994. Geographic Information Systems for geoscientists-modeling with GIS. Pergamon Press, Oxford, UK, 398.

Carranza, E. J. M. 2008. Geochemical anomaly and mineral prospectivity mapping in GIS, Handbook of 
Exploration Environmental Geochemistry. Elsevier, Amsterdam, Netherlands, 368.

Carranza, E.J.M., Hale, M. 2001. Geologically constrained fuzzy mapping of gold mineralization potential, Baguio district, Philippines. Natural Resources Research, 10, 125-136.

Dağdeviren, M. 2008. Decision making in equipment selection: an integrated approach with AHP and PROMETHEE. Journal of Intelligent Manufacturing, 19, 397-406.

Dağdeviren, M., Yavuz, S., Kılınç, N. 2009. Weapon selection using the AHP and TOPSIS methods under fuzzy environment. Expert Systems with Applications, 36, 8143-8151.

Feizi, F., Mansouri, E. 2012. Identification of Alteration Zones with Using ASTER Data in A Part of Qom Province, Central Iran, Journal of Basic and Applied Scientific Research, 2,73-84.

Feizi, F., Mansouri, E. 2013a. Separation of Alteration Zones on ASTER Data and Integration with Drainage Geochemical Maps in Soltanieh, Northern Iran, Open Journal of Geology, 3, 134-142.

Feizi, F., Mansouri, E. 2013b. Introducing the Iron Potential Zones Using Remote Sensing Studies in South of Qom Province, Iran. Open Journal of Geology, 3, 278-286.

Hassan-Nezhad, A.A., Moore, F. 2006. A stable isotope and fluid inclusion study of the Qaleh-Zari $\mathrm{Cu}-\mathrm{Au}-$ Ag deposit, Khorasan Province, Iran. Journal of Asian Earth Sciences. 27, 805-818.

Hwang, C.L., Yoon, K. 1981. Multiple Attribute Decision Making-Methods and Applications: A State of the Art Survey. Springer, New York.

Macharis, C., Springael, J., De Brucker, K., Verbeke, A. 2004. PROMETHEE and AHP: The design of operational synergies in multicriteria analysis: Strengthening PROMETHEE with ideas of AHP. European Journal of Operational Research, 153, 307-317.

Malczewski, J. 2006. Ordered weighted averaging with fuzzy quantifiers: GIS-based multicriteria evaluation for land-use suitability analysis, International Journal of Applied Earth Observation and Geo information, 8, 270-277.

Mansouri, E., Feizi, F., Karbalaei Ramezanali, A. A. 2015. Identification of magnetic anomalies based on ground magnetic data analysis using multifractal modelling: A case study in Qoja-Kandi, East Azerbaijan Province, Iran. Nonlinear Processes in Geophysics, 22, 579-587.
Najafi, A., Karimpour, M. H., Ghaderi, M. 2014. Application of fuzzy AHP method to IOCG prospectivity mapping: A case study in Taherabad prospecting area, eastern Iran. International Journal of Applied Earth Observation and Geoinformation, 33, 142154.

Noori, R., Feizi, F., Jafari, M. R. 2011. Determination of Cu and Mo Potential Targets in the Khatunabad Based on Analytical Hierarchy Process, West of Mianeh, Iran. World Academy of Science, Engineering and Technology, 78, 828-831.

Nouri, R., Jafari, M. R., Arain, M., Feizi, F. 2012. Hydrothermal Alteration Zones Identification Based on Remote Sensing Data in the Mahin Area, West of Qazvin Province, Iran. In Proceedings of World Academy of Science, Engineering and Technology 67, World Academy of Science, Engineering and Technology.

Novri, R., Afzal, P., Arian, M., Jafari, M., Feizi, F. 2013. Reconnaissance of Copper and Gold Mineralization Using Analytical Hierarchy Process (AHP) in the Rudbar 1: 100,000 Map Sheet, Northwest Iran. Journal of Mining and Metallurgy A: Mining, 49, 9-19.

Önüt, S., Soner, S. 2008. Transshipment site selection using the AHP and TOPSIS approaches under fuzzy environment. Waste Management, 28, 1552-1559.

Pazand, K., Hezarkhani, A., Ataei, M., Ghanbari, Y. 2011. Combining AHP with GIS for predictive $\mathrm{Cu}$ porphyry potential mapping: a case study in Ahar Area (NW, Iran). Natural resources research, 20, 251-262.

Pazand, K., Hezarkhani, A., Ataei, M. 2012. Using TOPSIS approaches for predictive porphyry $\mathrm{Cu}$ potential mapping: A case study in Ahar-Arasbaran area (NW, Iran). Computers \& Geosciences, 49, 62-71.

Pirmoradi, A., Vaezi, H., Baktash, P., Amiri, A. 2012. Role of SDI in index overlay Modeling and fuzzy logic in GIS to predict Malaria outbreak. Canada, Proceedings of Global Geospatial Conference 2012 Québec City, 14-17.

Porwal, A., Carranza, E.J.M., Hale, M. 2003. Artificial neural networks for mineral-potential mapping: a case study from Aravalli Province, Western India. Natural resources research, 12, 156-171.

Porwal, A., Carranza, E.J.M., Hale, M. 2004. A hybrid neuro-fuzzy model for mineral potential mapping. Mathematical Geology, 36, 803-826.

Porwal, A., Carranza, E.J.M, Hale, M. 2006. A hybrid fuzzy weights-of-evidence model for mineral potential mapping. Natural Resources Research, 15, 1-14. 
Purtov, V.K., Kholodnov, V.V., Anfilogov, V.N., Nechkin, G.S. 1989. The role of chlorine in the formation of magnetite skarns: International Geology Review. $31,63-71$.

Rogge, D.M., Halden, N.M., Beaumont-Smith, C. 2006. Application of data integration for shear-hosted $\mathrm{Au}$ potential modelling: Lynn Lake greenstone belt, northwestern Manitoba, Canada. GIS for the Earth Sciences, 44, 191-210.

Saaty, T.L. 1977. A scaling method for priorities in hierarchical structures. Journal of mathematical psychology, 15, 234-281.

Saaty, T.L. 1980. The analytic hierarchy process: planning, priority setting, resources allocation. New York: McGraw, pp, 281.

Saaty, T.L., 2005. The analytic hierarchy and analytic network processes for the measurement of intangible criteria and for decision-making." Multiple criteria decision analysis: state of the art surveys. Springer New York, 345-408.
Sahandi, M.R., Delavar, S.T., Sadeghi, M., Jafari, A., Moosavi, A. 2005. Geological Map of Iran (1:1.000.000). Geological Survey of Iran. <http:// www.ngdir.ir $>$.

Sokolov, G.A., Grigorev, V.M. 1977. Deposits of iron, in smirnov, V.I., ed., Ore deposits of the USSR: Pittman, London, 1, 7-13.

Vidal, C., Injoque-Espinoza, J., Sidder, G.B., Mukasa, S.B. 1990. Amphibolitic Cu-Fe skarn deposits in the central coast of Peru. Economic Geology, 85, 1447-1461.

Yousefi, M., Kamkar Rouhani, A. 2010. Principle of Mineral Potential Modeling Techniques (In Geographical Information System): Amirkabir University of Technology Press, Tehran.

Yousefi, M., Carranza, E. J. M. 2015. Prediction-area (PA) plot and C-A fractal analysis to classify and evaluate evidential maps for mineral prospectivity modeling. Computers \& Geosciences, 79, 69-81. 